\title{
Imported tradeware ceramics and their relevance for dating socio-political developments in South Sulawesi, with special reference to the Allangkanangnge ri Latanete site
}

\author{
David Bulbeck, Ian Caldwell, Stephen Druce, Budianto Hakim \\ and Campbell Macknight
}

\begin{abstract}
Imported high-fired ceramics (tradewares) are critical for dating early South Sulawesi historical sites between the $13 \mathrm{th} / 14 \mathrm{th}$ and $16 \mathrm{th} / 17 \mathrm{th}$ centuries $\mathrm{AD}$. The Allangkanangnge ri Latanete site is of great importance in the South Sulawesi context because of its large tradeware assemblage of more than 2000 sherds and its radiometric chronology that confirms the 13th/14th-16th/17thcentury dating assigned by ceramic specialists to the tradeware classes. The site is also of major importance in its local identification with the palace centre of Cina, an early Bugis kingdom. The combined chronological evidence from tradewares and chronometric determinations demonstrates a 14th-century antiquity for the deepest examples of the abundant rice phytoliths recovered from the site. Allangkanangnge ri Latanete exemplifies the major role of rice in the economy of the early Bugis agrarian kingdoms as their subsistence basis and as a source of surplus produce to trade for ceramics and other exotic imports.
\end{abstract}

Keywords: tradewares, South Sulawesi early history, Allangkanangnge ri Latanete, Cina, Bugis pre-Islamic kingdoms

\section{Introduction}

Remarkable quantities of stonewares and porcelains were imported to South Sulawesi throughout the 2nd millennium $\mathrm{AD}$. In an early study, a grand total of 14,611 imported ceramics classified by the local Archaeological Service includes five Tang identifications (AD 618-907), and about 10\% of the total identified as Song (AD 960-1279) and 1\% as Yuan (AD 1271-1368), with the remainder identified as post-Yuan Chinese, Thai, Vietnamese, Korean, Japanese and European. Possible Tang wares have also been identified in other South Sulawesi contexts, but the much larger volume of identifications of Song wares inspires more confidence in their status as a substantive category of imports (Hadimuljono and 
Macknight 1983). Review of the classificatory system applied by the local Archaeological Service, however, suggests that hardly any of the ceramics imported to South Sulawesi are of 12th-century or earlier antiquity, including the early Chinese whitewares and celadonlike monochromes that are best dated to the 13th/14th centuries, and black-on-white 'Jizhou' stoneware jars (Figure 16.1), which may date to as late as the 15 th century (Bulbeck 1992).

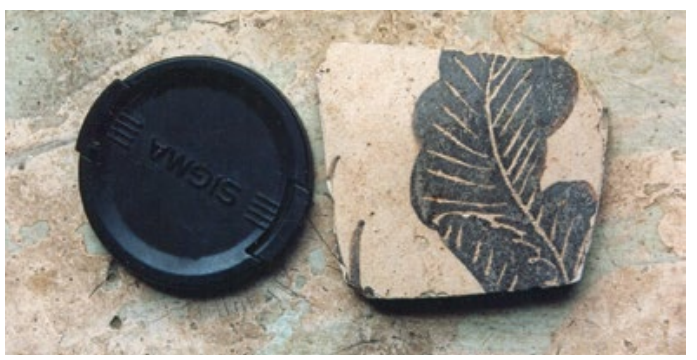

Figure 16.1: Jizhou sherd recovered during surface survey of the Pattimang Tua site immediately to the northwest of Utti Batue in Luwu.

Source: Photograph by David Bulbeck.
Historical records and archaeological inspections point to the use of large imported urns for burying the cremated remains of the deceased amongst the lowland Bugis of areas including Sawitto, Soppeng, Sengkang and its vicinity, and Bone (Lamuru to Watampone) between the 14th century and the conversion of South Sulawesi lowlanders to Islam in the early 17 th century (Bulbeck 1996-97:1035). On the other hand, Makasar and Selayar speakers evidently interred a range of imported ceramics with extended burials in late pre-Islamic times, before turning to the curation of tradewares as cherished household possessions during Islamic times (Hadimuljono and Macknight 1983). A combination of the central Bugis and Makasar/Selayar traditions was followed by the pre-Islamic Luwu Bugis and their Lemolang neighbours, who buried the ashes of the deceased in large jars but also accompanied the departed with a wealth of other ceramics (Caldwell 1994; Bulbeck 1996-97).

The 13th/14th-century dating for the earliest bulk importation of ceramics to South Sulawesi coincides with the zenith of the Majapahit Empire based in Java. The Desawanana, a Javanese poem written in 1365, claims four identifiable South Sulawesi places in the list of lands purportedly ruled by Majapahit: Makassar, Bantaeng, Luwu and Selayar (Robson 1995:34). The Makassar, Selayar and (in the vicinity of Utti Batue) Luwu archaeological programs encountered the greatest concentrations of sites with 13th/14th-century ceramics in South Sulawesi (Figure 16.2); these programs aimed to exhaustively document pre-Islamic burial grounds in the study region (Naniek 1983; Wibisono 1985; Bulbeck 1992; Bulbeck and Caldwell 2000). The lighter concentration of these sites recorded during the Bantaeng survey is because its survey methodology relied predominantly on summarising looters' general accounts of the antiques they had unearthed (Bougas 1998). Subsequent research in Bantaeng recovered hundreds of tradewares including sherds from six sites dated to the 13th/14th centuries (no more closely identified; Nayati 2005:Table 6) and Song ${ }^{1}$ and Yuan ceramics (Hajramurni 2011); unfortunately, details of the archaeological work have not yet been published. The overall interpretation recommended for Figure 16.2 is that 13th/14th-century ceramics reached widely across the South Sulawesi lowlands.

1 Presumably Southern rather than Northern Song. 


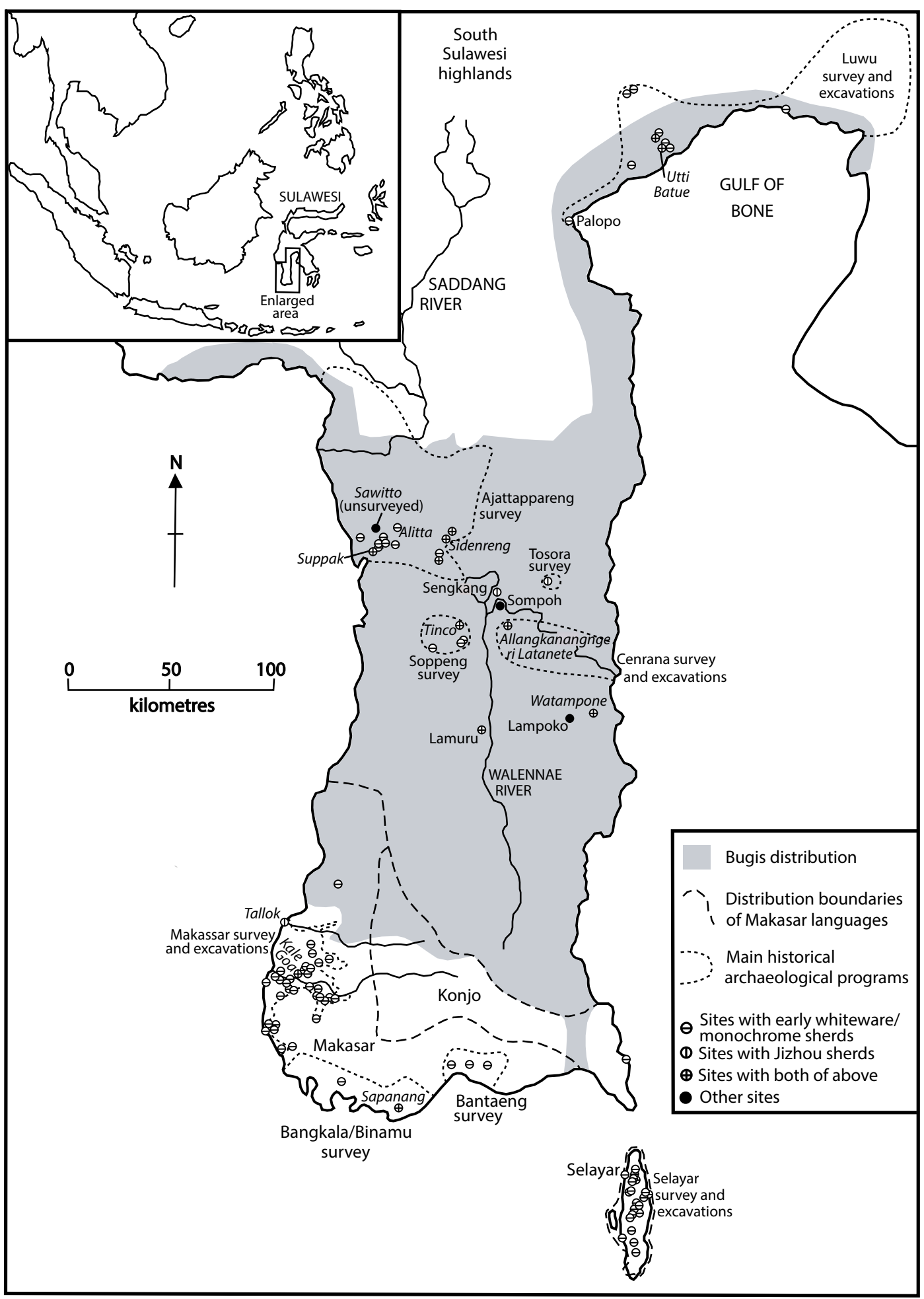

Figure 16.2: South Sulawesi with places discussed in the text (suspected pre-Islamic palace centres italicised) and sites with early whiteware/monochrome and jizhou sherds.

Sources: Oudheidkundige Dienst in Indonesia (1949:12-13); Naniek (1983); Wibisono (1985); Kallupa et al. (1989); Bulbeck (1992); Bulbeck (1996-97); Bougas (1998); Bulbeck and Caldwell (2000); Caldwell and Bougas (2004); Druce (2009); Bulbeck laboratory notes for Tosora, Sengkang and Lamuru. 
Sources on early Bugis history include indigenous texts that derive from the development of a Bugis script at around AD 1400 (Caldwell 1995) and European sources dating from the 16th century. In the 17th century, the main Makasar and Bugis kingdoms initiated a tradition of compiling 'chronicles' that typically covered the kingdom's mythological foundations, the sequence of rulers and their family relationships, and the major achievements and developments associated with particular reigns. Macknight (1983) recognised the value of the chronicle of Bone for its documentation of the expansion of centrally sponsored wet-rice production, after $\mathrm{AD} 1400$, across the coastal belt that constituted the heartland of this Bugis kingdom in later centuries. Kallupa et al. (1989) developed on Macknight's approach through archaeological survey of the major toponyms cited in the origin tradition of the Bugis kingdom of Soppeng. The identifications of the collected tradewares, combined with chronological reckoning of the genealogical records, led Kallupa et al. (1989:83) to propose the establishment of Soppeng as a centralised agrarian kingdom by the 13th century. In a similar vein, identifications of collected tradewares formed the basis for a c. AD 1300 estimate for the origins of concerted wet-rice production in the southern Ajattappareng region (Druce 2009) and in the vicinity of Kale Goa, the heartland of the Makasar-speaking kingdom of Goa (Bulbeck 1992).

A further step in this general research program was undertaken by the Origin of Complex Society in South Sulawesi (OXIS) project (Bulbeck and Caldwell 2000). The OXIS project targeted the legendary origins of Bugis kingship through its investigation of sites associated with the Luwu and Cina polities that figure in the cycle of Bugis stories associated with the name La Galigo. The aim was to resolve the discrepancy between the 11th to 13th century dating for the 'Age of La Galigo', as believed by many scholars of South Sulawesi history (e.g. Zainal Abidin 1974; Pelras 1996), and the lack of solid historical evidence for these polities' existence prior to the 14th century (Caldwell 1988).

The investigation that constitutes the focus of this contribution was carried out in June and July 2005 at Allangkanangnge ri Latanete, 'The Palace Site on the Hill' (hereafter, Allangkanangnge), in the western Cenrana valley. Allangkanangnge is a hilltop site in the village of Sarapao, Kabupaten Wajo, $6 \mathrm{~km}$ southeast of the regional capital Sengkang (Figure 16.2). The hill, which rises some metres above the rice fields to its east, forms part of a low molasse ridge that runs north-south through Sengkang. The hill is identified locally as the palace site of Cina, an important kingdom in the La Galigo stories. This cycle, which covers seven generations of a semi-divine ruling family, is believed to contain a collective memory of the early development of complex chiefdoms (Pelras 1996). Cina is portrayed as a large and powerful kingdom that dominated the central rice-growing lands of the South Sulawesi peninsula and controlled trade with the outside world. Indeed, based on their review of the historical and archaeological evidence for the Cenrana valley, Caldwell and Wellen (2017) propose that it can be identified with Uda, the fifth South Sulawesi toponym mentioned in the Desawanana, which previously had not been matched to a particular location.

\section{Allangkanangnge survey and surface collections}

The Allangkanangnge hill extends approximately $550 \mathrm{~m}$ north-south by $400 \mathrm{~m}$ east-west (Figure 16.3). Today it is free of permanent dwellings and is planted with vegetables, tobacco, cacao, maize and other cash crops. It includes a raised earth platform of around $1000 \mathrm{~m}^{2}$ $(35 \mathrm{~m} \times 30 \mathrm{~m})$ on its northeastern shoulder. On this platform are a dozen substantial stone graves, built in a variety of Islamic styles; these are claimed to be the graves of the rulers of Cina. The earth platform is edged with stone retaining walls that appear to be original and largely undisturbed. This platform, which is visited daily by people seeking blessings and favours, was likely the location of the palace from which the hill obtains its name. 


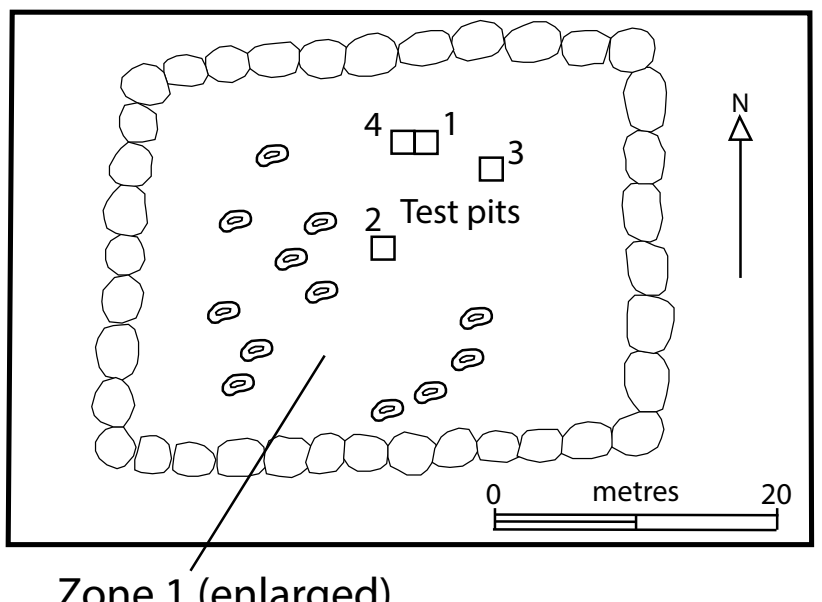

\begin{tabular}{|ll|}
\hline 0 & Old graves \\
0 & Stone lines \\
30000 & Bamboos/ \\
S & Fencing \\
Gardens \\
Legend
\end{tabular}

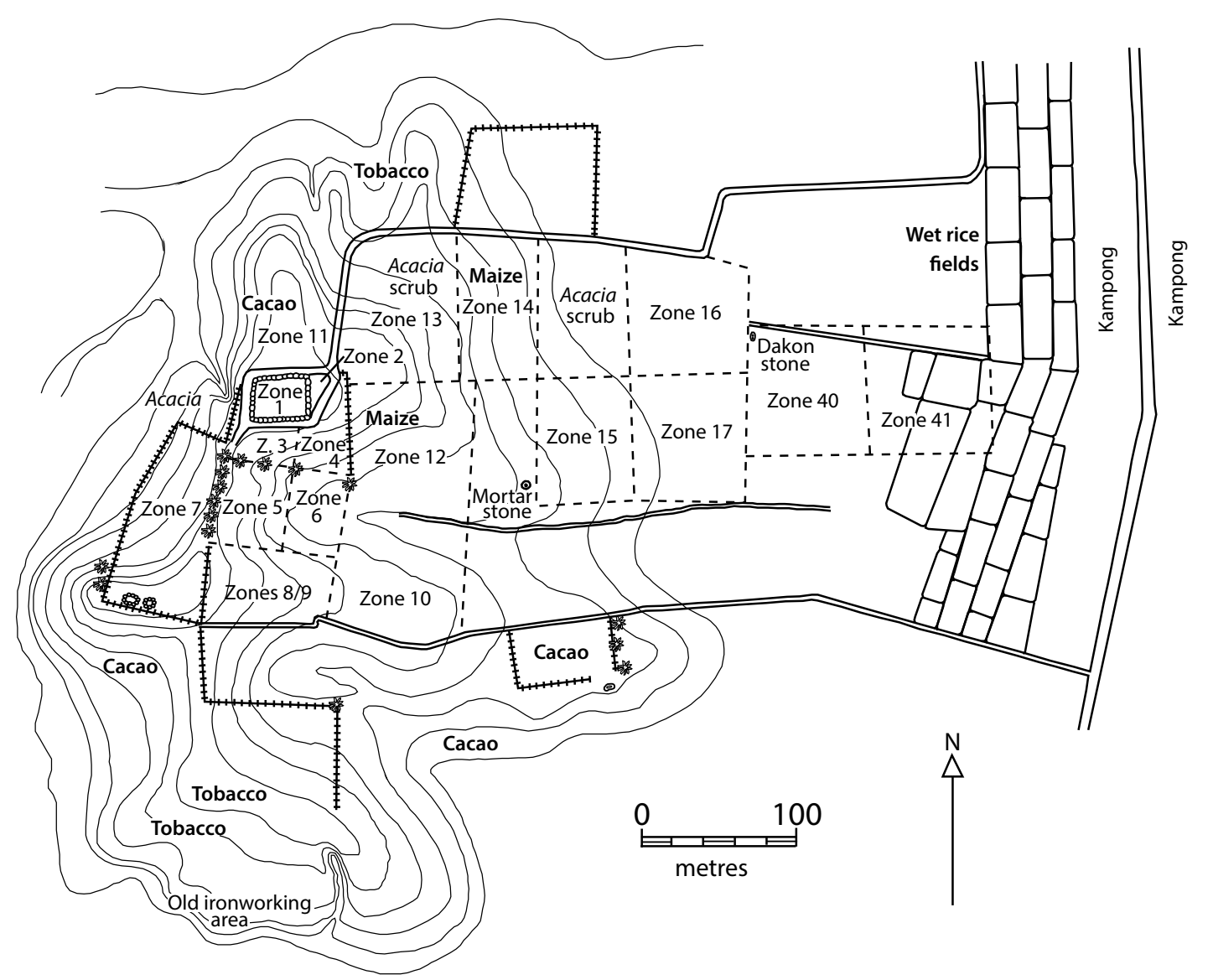

Figure 16.3: Theodolite survey of Allangkanangnge ri Latanete and collection zones (2005).

Source: Pak Mansur, Makassar Archaeology office.

Early work at the Allangkanangnge site resulted in the recovery of 58 tradeware sherds, which Orsoy de Flines, the ceramics expert working for the Dutch colonial archaeological service, dated to between the 15th and 17th centuries (Bulbeck 1996-97:1047). Later, Kaharuddin (1994) sketched the location of a royal installation stone, stone graves and old wells, and made a surface collection of earthenware and 151 tradeware sherds. Nearly half of the imported ceramics were classified as 'yellow and brown' (Jizhou?) and half of the remainder as 'blue' (blue and white), 
followed by small percentages of celadons, whitewares, blackwares and brownwares. Kaharuddin further classified 34 of the sherds by vessel form: 11 martavans (large stoneware jars), 10 plates, seven bowls and six jars.

In July 1999, the OXIS project mapped five locales on the hilltop and opened a $1 \mathrm{~m}$ x $1 \mathrm{~m}$ test pit on the raised earth platform (Bulbeck and Caldwell 2000). Archaeological work was resumed by an international team of researchers over five days in June and July 2005. The hill and flats to the east were mapped using a theodolite and the 1999 excavations were extended (see below). ${ }^{2}$ The site was divided into 41 zones, including 19 where surface materials were collected, assisted by the recent clearing of the hill surface for planting crops (Figure 16.3). The available surface collection of tradewares includes 251 collected in 1999 and 1869 collected in 2005, making a total of 2120 sherds (Table 16.1). Several of the earlier classes, notably the Dehua and Qingbai whiteware classes and the Jizhou class, had long histories of production prior to the earliest examples reaching South Sulawesi (Bulbeck 1992:Appendix B). The ceramic class age estimates used here are taken from Bulbeck and Caldwell (2000).

Table 16.1 and Figure 16.4 show that tradewares of all ages, from the 13th/14th to the 19 th/20th centuries, were distributed widely across the site. Around $95 \%$ of the sherdage is 17 th century or earlier in age and reflects the residential occupation of the site from the 13th century to the mid-17th century. Thereafter, Allangkanangnge appears to have been abandoned, probably as a result of the harrowing of Wajo in 1670 by La Tenritatta, the ruler of Bone (Andaya 1981). The remaining $5 \%$ of the collected sherdage reflects the site's subsequent use for dryland gardening and the veneration of ancestral stone graves, notably along the southern ridge (see below).

Table 16.1: Imported ceramics collected from the Allangkanangnge surface in 1999 and 2005.

\begin{tabular}{|c|c|c|c|c|c|c|}
\hline Ceramic type & $\begin{array}{c}\text { Centuries } \\
A D\end{array}$ & $\begin{array}{c}\text { Hilltop } \\
\text { summit }^{(a)}\end{array}$ & $\begin{array}{l}\text { Southern } \\
\text { ridge }^{(b)}\end{array}$ & Slopes $(c)$ & $\begin{array}{l}\text { Eastern } \\
\text { flats }^{(d)}\end{array}$ & Total \\
\hline Dehua whiteware & $13-14$ & 30 & 7 & 28 & 14 & 79 \\
\hline Qingbai whiteware & $13-14$ & - & 1 & 2 & - & 3 \\
\hline Yuan celadon & $13-14$ & 2 & 1 & 6 & - & 9 \\
\hline Chinese martavan & $13-17$ & 227 & 227 & 198 & 54 & 706 \\
\hline Yuan overglaze enamelled & 14 & - & - & 1 & - & 1 \\
\hline jizhou iron-painted martavan & $14-15$ & 19 & 10 & 19 & 5 & 53 \\
\hline jizhou iron-painted bowl & $14-15$ & 2 & - & - & - & 2 \\
\hline Yuan/Ming celadon & $14-15$ & 3 & - & - & - & 3 \\
\hline Ming whiteware & $14-16$ & 1 & 2 & 5 & - & 8 \\
\hline Vietnamese monochrome & $14-16$ & 6 & 9 & 21 & 4 & 40 \\
\hline Vietnamese martavan & $14-17$ & 46 & 113 & 76 & 28 & 263 \\
\hline Sancai lead-glazed vases & 15 & 2 & 1 & 14 & - & 17 \\
\hline Sukothai plate & $15-16$ & - & - & 1 & 1 & 2 \\
\hline Vietnamese blue-and-white/overglaze red & $15-16$ & 3 & 2 & 14 & 2 & 21 \\
\hline Sawankhalok celadon/monochrome & $15-16$ & 51 & 43 & 48 & 18 & 160 \\
\hline Thai jar/martavan & $15-16$ & 11 & 3 & 7 & 5 & 26 \\
\hline Ming celadon & $15-17$ & 16 & 13 & 36 & 6 & 71 \\
\hline Sawankhalok black-and-white & 16 & 1 & - & 1 & - & 2 \\
\hline Ming blue-and-white & 16 & 44 & 32 & 77 & 56 & 209 \\
\hline
\end{tabular}

2 Ali Fadillah, then Director of the Makassar Archaeology Office, directed the 1999 survey and excavations, assisted by Ian Caldwell and Budianto Hakim. Ian Caldwell, Steven Druce and Campbell Macknight directed the 2005 survey, and Budianto Hakim directed the 2005 excavations. The imported ceramic sherds were identified by Karaeng Demmanari, a Makassar expert in tradewares, assisted by David Bulbeck. Ceramic textbooks were used to assist the identifications, e.g. Guy (1986) and Harrisson (1990). 


\begin{tabular}{|c|c|c|c|c|c|c|}
\hline Ceramic type & $\begin{array}{c}\text { Centuries } \\
\text { AD }\end{array}$ & $\begin{array}{c}\text { Hilltop } \\
\text { summit }^{(\mathrm{a})}\end{array}$ & $\begin{array}{l}\text { Southern } \\
\text { ridge }^{(b)}\end{array}$ & Slopes ${ }^{(c)}$ & $\begin{array}{l}\text { Eastern } \\
\text { flats }^{(d)}\end{array}$ & Total \\
\hline Ming red/green overglaze enamelled & 16 & 1 & 2 & 2 & - & 5 \\
\hline Ming Swatow & 16 & 5 & 8 & 20 & 6 & 39 \\
\hline Wanli whiteware/blue-and-white & $\begin{array}{l}\text { Late } 16- \\
\text { early } 17\end{array}$ & 2 & 8 & 2 & 2 & 14 \\
\hline Transitional whiteware/blue-and-white & 17 & 5 & 2 & 2 & - & 9 \\
\hline Swatow & 17 & 40 & 30 & 88 & 78 & 236 \\
\hline Qing blue-and-white & Late $17-19$ & 12 & 59 & 23 & 10 & 104 \\
\hline Japanese blue-and-white stamped ware & $19-20$ & - & - & 4 & 1 & 5 \\
\hline Qing celadon & $19-20$ & - & 4 & 1 & 1 & 6 \\
\hline European & $19-20$ & 3 & 9 & 9 & 5 & 26 \\
\hline Qing whiteware & 20 & 1 & -1 & - & - & 1 \\
\hline Total & & 533 & 586 & 705 & 296 & 2120 \\
\hline
\end{tabular}
(a) Upper Locales 1 and 2 (1999) and Zones 1, 2, 3 and 11 (2005).
(b) Locale 4 (1999) and Zones 7-9 (2005).
(c) Lower Locales 1 and 2, Locales 3 and 5 (1999) and Zones 4-6, 10-12, 14-15 (no tradewares in Zone 13) and 18-20 (2005).
(d) Zones 16, 17, and 40-41 (2005).

Source: David Bulbeck's laboratory notes.

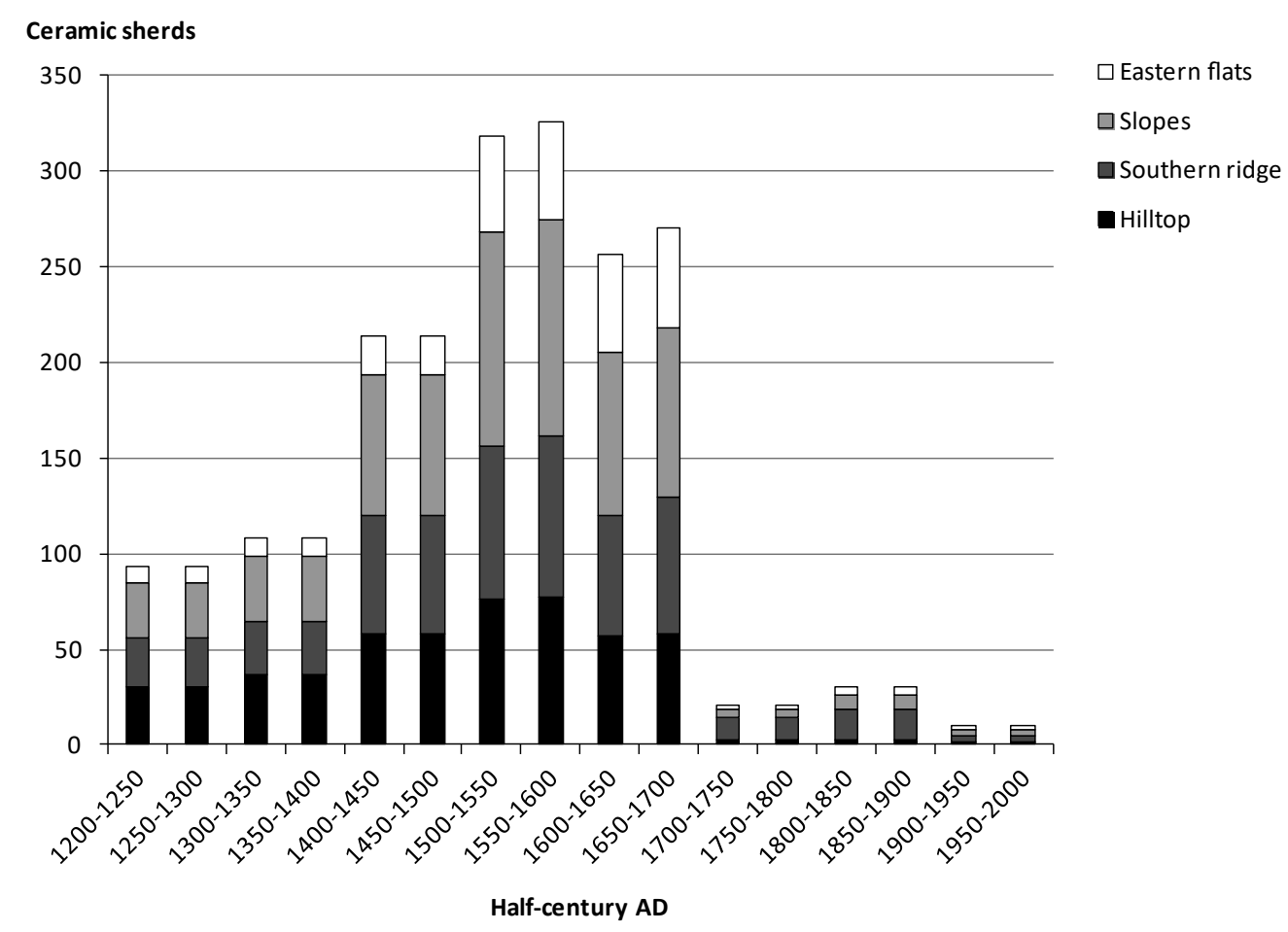

Figure 16.4: Histogram of Allangkanangnge tradeware identifications distributed by half-century AD. Source: Data from Table 16.1. 
Proportionate analysis of the ceramic identifications in terms of their location is presented in Table 16.2. Nearly half of the sherdage (49\%) is classified as large martavan jars, with the highest proportion on the hilltop summit (57\% of all sherds) and the ridge immediately to its south ( $60 \%$ of all sherds), and the lowest proportion on the eastern flats (31\% of all sherds). The distinction between the summit and southern ridge collections lies in the non-martavan identifications. These are earlier for the summit and appreciably younger for the southern ridge (for instance, $6 \%$ of the summit collection comprises 13 th-14th century non-martavan sherds and just 3\% comprises late 17 th-20th century non-martavan sherds, compared with $1.5 \%$ and $12 \%$ respectively for the southern ridge collection). The slope and eastern flats collections are intermediate in this regard, although the eastern flats collection stands out in that nearly half of it dates to between the 16th to early 17 th centuries.

Table 16.2: Topographic distribution of the Allangkanangnge tradeware surface collection (\%).

\begin{tabular}{|l|r|r|r|r|r|}
\hline Analytical ceramic category & $\begin{array}{c}\text { Hilltop } \\
\text { summit }\end{array}$ & $\begin{array}{c}\text { Southern } \\
\text { ridge }\end{array}$ & \multicolumn{1}{c|}{ Slopes } & \multicolumn{1}{c|}{$\begin{array}{c}\text { Eastern } \\
\text { flats }\end{array}$} & Total \\
\hline jizhou martavan & 3.9 & 1.7 & 2.7 & 1.7 & 2.6 \\
\hline Other Chinese martavan (13th-17th centuries) & 42.6 & 38.7 & 28.1 & 18.2 & 33.3 \\
\hline Vietnamese martavan (14th-17th centuries) & 8.6 & 19.3 & 10.8 & 9.5 & 12.4 \\
\hline Thai jar/martavan (15th-16th centuries) & 2.1 & 0.5 & 1.0 & 1.7 & 1.2 \\
\hline Other types 13th-14th centuries & 6.0 & 1.5 & 5.2 & 4.7 & 4.3 \\
\hline Other types 14th-15th centuries & 1.9 & 1.9 & 3.7 & 1.4 & 2.4 \\
\hline Other types 15th-17th centuries & 13.5 & 10.1 & 16.0 & 9.1 & 12.8 \\
\hline Other types 16th to early 17th centuries & 18.4 & 14.0 & 27.2 & 48.0 & 24.2 \\
\hline Other types late 17th-20th centuries & 3.0 & 12.3 & 5.2 & 5.7 & 6.7 \\
\hline Total & 100.0 & 100.0 & 100.0 & 100.0 & 100.0 \\
\hline
\end{tabular}

Note: Percentages may not sum exactly to $100.0 \%$ due to rounding.

Source: Compilations of the figures presented in Table 16.1.

Scattered across the southern ridge and in various locations on the lower slopes are some dozens of highly disturbed stone arrangements. Two of the clearer examples were mapped in the southwestern corner of Zone 7 (Figure 16.2), but many examples are now difficult to discern. The pattern of these arrangements is a rectangular platform or enclosure, with a standing stone in the centre. Some of these standing stones are sculpted to show a rudimentary head. These evoke the menhirs at Sompoh and the field of rectangular tumuli at Lampoko, associated with the disturbed remnants of cremated human remains in martavans and with other 15th17th-century tradeware sherds (van Heekeren 1958:84-85; Bulbeck 1996-97:1035). Thus, the southern ridge appears to have been a zone of concentrated burial of cremated human remains, as recorded widely for lowland Bugis in the South Sulawesi peninsula. This interpretation would explain the high proportion of martavan sherds in the southern ridge collection, as well as its paucity of 13th/14th-century tradeware sherdage (if the main focus of the Bugis tradition of pre-Islamic cremations spanned the 15th and 16th centuries), and its relatively high proportion of Islamic-period tradewares (brought to the graves as offerings to the ancestors).

In summary, while imported sherdage of all types and all ages were found distributed across the site, martavan sherds were most concentrated on the hilltop summit and southern ridge, and the older ceramic classes most concentrated on the hilltop summit. 


\section{Site excavation and chronology}

Four $1 \mathrm{~m}^{2}$ test pits (TP) were excavated on the raised earth platform within the walled area containing old graves (Zone 1). TP1 was placed near the north stone wall, TP2 near the centre of the platform, TP3 towards the east stone wall, and TP4 extended TP1 $1 \mathrm{~m}$ to the west (Figure 16.3). TP1 had been excavated in 1999 to a depth of around $0.4 \mathrm{~m}$ and then backfilled (Bulbeck and Caldwell 2008). This backfill was removed in 2005 and four further spits were excavated to sterile soil at a depth of $0.85 \mathrm{~m}$. The other three test pits were excavated in $10-20 \mathrm{~cm}$ spits to sterile soil. A single unit of $40 \mathrm{~cm}$ was removed below the lowest spit of TP4 to include a distinctive feature that descended into the sterile soil.

The stratigraphy in each of the test pits included deposit recorded during excavation as dark silty sand in the upper spits and yellowish silty sand in the lower spits. ${ }^{3}$ The dark sand contained the denser remains of habitation, whereas the yellow sand extended between deposit with light evidence for occupation higher up and sterile deposit at the base. TP4 was unusual in having a hole filled with black sand at the base of the excavation. All test pits produced one or more tradeware sherds, with their identifications provided in Table 16.3. Their estimated age in relation to stratigraphic depth and radiometrically dated samples (calibrated using Oxcal 4.2; Bronk Ramsey 2016) are illustrated in Figures 16.5-16.8.

Table 16.3: Tradewares excavated from Allangkanangnge.

\begin{tabular}{|l|l|l|l|l|}
\hline Ceramic identification & TP1 & TP2 & TP3 & TP4 \\
\hline C11-12 Vietnam/Guangdong brownware & Spit 6 & - & - & - \\
\hline C12-14 'Yueh' olive-greenware & Spit 4 (2) & - & Spit 3 & - \\
\hline C13-14 Dehua whiteware & - & - & Spit 3 & - \\
\hline C13-14 Yuan celadon & Spit 6 & - & - & - \\
\hline C14 Dehua whiteware & Spit 7 & - & - & - \\
\hline C14-15 Dehua whiteware & Spit 5 & - & Spit 3 & - \\
\hline C14-15 Ming celadon & Spit 5 & - & - & - \\
\hline C15 Sancai & - & - & Spit 1 & - \\
\hline C15 Ming whiteware & - & - & Spit 2 & - \\
\hline C15 Ming celadon & - & - & Spit 1 & Spit 3 \\
\hline C15-16 Sawankhalok tempayan & Spit 5 & - & - & - \\
\hline C15-16 Thai coarse brownware tempayan & Spit 1 & - & - & - \\
\hline C15-16 Guangdong brownware tempayan & Spit 4; Spit 5 (2) & - & - & Spit 3 \\
\hline C15-16 Go Sanh tempayan & Spit 4 (2) & - & - & Spit 2 \\
\hline C15-16 Ming celadon & Spits 2, 3, 4 & - & - & - \\
\hline C16 Sawankhalok black-and-white & Spit 2 & - & - & - \\
\hline C16 Ming blue-and-white & - & Spit 1 & - & - \\
\hline C16 Ming Swatow blue-and-white & Spits 1, 2 & - & - & - \\
\hline C16-17 Ming Wanli blue-and-white & Spit 3 & - & - & - \\
\hline C15-17 Guangdong brownware tempayan & Surface (2), Spit 1, Spit 3 (3) & - & Spit 1 & - \\
\hline C16-17 Coarse red tempayan & - & - & Spit 1 & Spit 5 \\
\hline
\end{tabular}

Source: David Bulbeck's laboratory notes.

3 Munsell colour readings were taken only for the sediment in Spits 1-6 of TP1, which was consistently very dark grey (Hakim et al., this volume). For consistency's sake, the sediment colours in Figures 16.5-16.8 are field descriptions. 


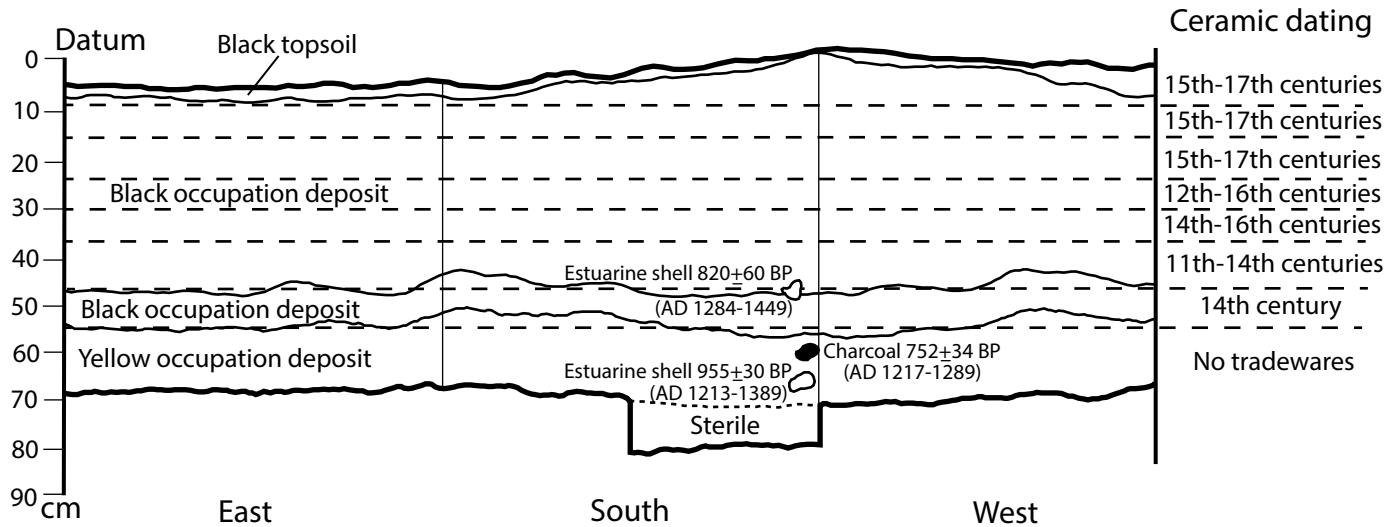

Figure 16.5: East, south and west stratigraphic sections of TP1, Allangkanangnge ri Latanete, with tradeware datings.

The figure is a composite of the 1999 and 2005 excavations. The lower black excavation deposit relates to the resumption of excavation in 2005.

Source: Budianto Hakim's fieldwork records.

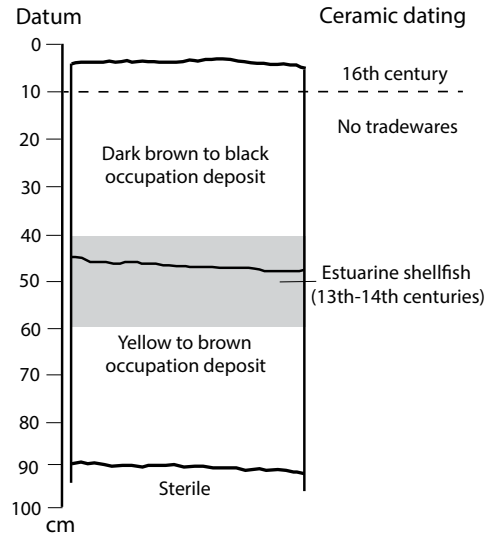

Figure 16.6: Stratigraphic section of northwest wall of TP2, Allangkanangnge ri Latanete, with tradeware dating.

Source: Budianto Hakim's fieldwork records.

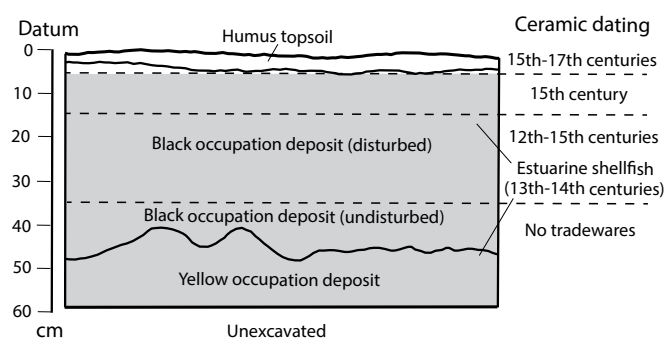

Figure 16.7: Stratigraphic section of west wall of TP3, Allangkanangnge ri Latanete, with tradeware datings.

Source: Budianto Hakim's fieldwork records.

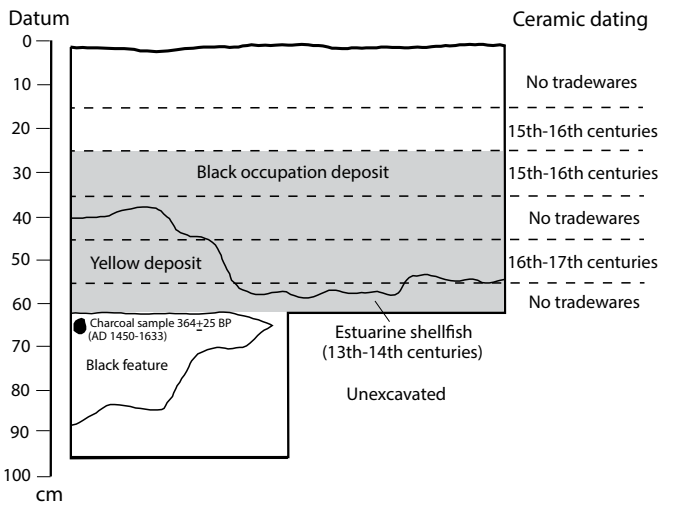

Figure 16.8: Stratigraphic section of west wall of TP4, Allangkanangnge ri Latanete, with tradeware datings.

Source: Budianto Hakim's fieldwork records.

Field records from the 1999 and 2005 excavations of TP 1 were combined for analysis and the result is presented here as a single excavation. The most consistent interpretation of depth and age is obtained by focusing on the upper limit of the range of tradeware date estimates (Figure 16.5). This would imply a dating of around the 17th century for Spits 1-3, the 16th century for Spits 4 and 5, and the 14th century for Spits 6 and 7. This chronological interpretation indicates increasing age of the recovered ceramics with increasing stratigraphic depth. 
The three radiometrically dated samples support this chronology. After allowing for the marine reservoir effect, the upper estuarine shell sample recovered from the base of Spit 6 and dated to $820 \pm 60$ BP (ANU-11352) has a median calibrated date in the 14th century. This corresponds to the 14th-century dating for Spits 6 and 7 inferred from the tradewares. The two radiometrically obtained dates from Spit 8, which produced no tradewares, suggest initial occupation in the 13th century: one date spans the 13 th-14th centuries and one lies squarely in the 13 th century. ${ }^{4}$

The excavation of TP2 produced only a modest quantity of remains (Hakim et al., this volume). Nonetheless, the 16th-century dating for its single tradeware, from Spit 1 (Figure 16.6), is consistent with the inferred dating of the late occupation of the site to the 16th/17th centuries, and with a 13th/14th-century dating for the estuarine shellfish (as indicated by the radiometric dates on the TP1 shellfish) from the interface between the dark and yellow occupation deposit at Spit 4, three spits beneath Spit 1.

TP3 produced a small number of sherds from the top three spits, which include a topsoil layer and a disturbed deposit in the second and third spits. The topsoil and underlying disturbed deposit would be respectively dated to the 17 th and 15 th centuries, with reference to the upper limit of the range of ceramic datings (Figure 16.7). The presence of estuarine shellfish throughout most of the deposit is consistent with a 13th/14th-century onset of occupation corresponding to the undisturbed deposit at excavated depths beneath $35 \mathrm{~cm}$, and the incorporation of some of these shellfish remains within the overlying disturbed occupation deposit.

TP4 is more problematic in terms of its chronological implications. The simplest interpretation is a 16th-century dating throughout the deposit, including the median calibrated date of the charcoal sample $(364 \pm 25$ BP, Wk-29737) recovered from the black sandy feature towards the base of the excavation. However, there is a suggestion of an inverted stratigraphy in that 13th/14th-century estuarine shellfish (predominantly Telescopium telescopium) was recovered throughout much of the deposit that lies above the black sandy feature (Figure 16.8). As discussed elsewhere (Hakim et al., this volume), this stratigraphic inversion would be consistent with the burial of human cremated remains within the black feature to produce the sample submitted for Carbon-14 dating.

An important finding from the 1999 OXIS excavation was the recovery of large numbers of rice phytoliths (approximately 500 to 1700) from each of the 5 g sediment samples in TP1 Spits 1 to 6 . The phytoliths reflect the pounding and final winnowing of rice that had been cultivated and harvested elsewhere. It is not possible to say whether the rice was from dryland or wetland fields, but they provide a record of rice cultivation between the 14th and 16th/17th centuries (Bulbeck and Caldwell 2008). Sediment samples were not collected during the 2005 excavations and we are unable to report on phytolith evidence from any of the other excavated spits. We are, however, able to infer occupation at Allangkanangnge by the 13th century.

\section{Imported ceramics analysis}

Initial occupation of Allangkanangnge can be securely dated to the 13th century based on the two deepest radiometric dates obtained from TP1 (Figure 16.5). The only suggestion of earlier occupation derives from the c. 12th-century dating proposed for the Vietnam/Guangdong brownware sherd from Spit 6 in TP1 and the 'Yueh' olive-greenware sherds in TP1 and TP3 (Table 16.3). However, there are two reasons why this 12 th-century dating should not be taken

4 With regard to the radiometrically dated samples of marine shellfish, the upper sample was the Telescopium telescopium gastropod and the lower sample was the Pinctada margaritifera oyster (Hakim et al., this volume, where the uncertainties of the resulting dates are discussed). 
at face value. First, small tradeware sherds can be difficult to identify; second, tradewares may have remained in use long after the time of their manufacture (Fenner and Bulbeck 2013). ${ }^{5}$ The c. 13th-century basal dating for a substantial number of Allangkanangnge tradewares (Table 16.1) agrees with the site's earliest radiometric dates, pointing to initial occupation during that century.

Occupation of Allangkanangnge until the 16th/17th centuries is indicated by the most recent of the excavated tradeware sherds (Table 16.3), and by the charcoal date from TP4, even if the sample suffers from stratigraphic inversion (Figure 16.8). The final date for the main period of occupation can be further narrowed to the 17 th century based on the 17 th-century dating of a large number of sherds from the surface collection (Table 16.1).

The ceramic evidence from Allangkanangnge corresponds with that from Tinco, an early Bugis pre-Islamic palace centre in the Walennae valley. A survey in 1986 yielded a large surface collection of 2180 imported ceramic sherds (Kallupa et al. 1989) and recent work by Hasanuddin (2015) has produced Carbon-14 dates. Both sites now have Carbon-14 dates between the 13th and 16th/17th centuries $\mathrm{AD}$ and a corresponding preponderance of 13th/14th-17th-century imported ceramics (Table 16.4). The site of Talaborong in Gowa, with its potentially pre-13thcentury date and ceramics dating back to the 12th century, hints at an even earlier onset for the arrival of imported ceramics into South Sulawesi, but may be more prudently interpreted as consistent with the Allangkanangnge/Tinco chronology. This is certainly the case for the Salabu and Pinanto sites in Luwu, whose 15th-17th-century ceramics correspond well with their median 15th-17th-century Carbon-14 dates. In summary, where Carbon-14 determinations can be related to imported ceramics at Allangkanangnge and other South Sulawesi sites, their dating is in good agreement.

Table 16.4: Carbon-14 dates on charcoal and bone from South Sulawesi sites with imported ceramics.

\begin{tabular}{|c|c|c|c|c|c|c|}
\hline Site & Date & $\begin{array}{l}\text { Laboratory } \\
\text { code }\end{array}$ & Dated material & $\begin{array}{l}95 \% \\
\text { calibrated } \\
\text { range }^{(\mathrm{a})} \\
\end{array}$ & \begin{tabular}{|l} 
Main \\
ceramics \\
dating \\
\end{tabular} & Reference(s) \\
\hline Talaborong, Gowa(b) & $920 \pm 70 \mathrm{BP}$ & ANU 5924 & $\begin{array}{l}\text { Burnt bone } \\
\text { collected from } \\
\text { site surface }\end{array}$ & $\begin{array}{l}A D \\
720-1392\end{array}$ & $\begin{array}{l}\text { 12th-14th } \\
\text { centuries }\end{array}$ & Bulbeck 1992 \\
\hline Tinco, Soppeng & $760 \pm 30 \mathrm{BP}$ & Beta-324215 & $\begin{array}{l}\text { Excavated } \\
\text { charcoal }\end{array}$ & $\begin{array}{l}A D \\
1218-1283\end{array}$ & $\begin{array}{l}\text { 13th/14th- } \\
\text { 17th centuries }\end{array}$ & $\begin{array}{l}\text { Hasanuddin 2015; } \\
\text { Kallupa et al. } 1989\end{array}$ \\
\hline Allangkanangnge & $752 \pm 34 \mathrm{BP}$ & Wk-17818 & $\begin{array}{l}\text { Excavated } \\
\text { charcoal }\end{array}$ & $\begin{array}{l}A D \\
1217-1289\end{array}$ & $\begin{array}{l}\text { 13th/14th- } \\
\text { 17th centuries }\end{array}$ & This paper \\
\hline Salabu, Luwu & $400 \pm 60 \mathrm{BP}$ & Wk-7336 & $\begin{array}{l}\text { Excavated pig } \\
\text { tooth }\end{array}$ & $\begin{array}{l}\text { AD } \\
1424-1637\end{array}$ & $\begin{array}{l}\text { 15th-17th } \\
\text { centuries }\end{array}$ & $\begin{array}{l}\text { Bulbeck and } \\
\text { Caldwell } 2000\end{array}$ \\
\hline Pinanto, Luwu & $390 \pm 90 \mathrm{BP}$ & ANU 11355 & $\begin{array}{l}\text { Excavated } \\
\text { charcoal } \\
\end{array}$ & $\begin{array}{l}A D \\
1323-1796 \\
\end{array}$ & $\begin{array}{l}\text { 15th-17th } \\
\text { centuries }\end{array}$ & $\begin{array}{l}\text { Bulbeck and } \\
\text { Caldwell } 2000 \\
\end{array}$ \\
\hline Tinco, Soppeng & $380 \pm 30 \mathrm{BP}$ & Beta-324216 & $\begin{array}{l}\text { Excavated } \\
\text { charcoal }\end{array}$ & $\begin{array}{l}A D \\
1440-1630\end{array}$ & $\begin{array}{l}\text { 13th/14th- } \\
\text { 17th centuries }\end{array}$ & $\begin{array}{l}\text { Hasanuddin 2015; } \\
\text { Kallupa et al. } 1989\end{array}$ \\
\hline Allangkanangnge & $364 \pm 25 B P$ & Wk-29737 & $\begin{array}{l}\text { Suspected } \\
\text { human ashes }\end{array}$ & $\begin{array}{l}A D \\
1450-1633\end{array}$ & $\begin{array}{l}\text { 13th/14th- } \\
\text { 17th centuries }\end{array}$ & This paper \\
\hline Tinco, Soppeng & $320 \pm 30 \mathrm{BP}$ & Beta-324217 & $\begin{array}{l}\text { Excavated } \\
\text { charcoal }\end{array}$ & \begin{tabular}{|l}
$A D$ \\
$1481-1644$
\end{tabular} & \begin{tabular}{|l|} 
13th/14th- \\
17th centuries
\end{tabular} & $\begin{array}{l}\text { Hasanuddin 2015; } \\
\text { Kallupa et al. } 1989\end{array}$ \\
\hline
\end{tabular}

(a) Calibrated using 0xcal 4.2 (Bronk Ramsey 2016).

(b) Recorded during the Makassar survey. The date was obtained from the apatite fraction of the bone, which reduces the date's reliability (Bulbeck, this volume).

5 Indeed, the lowest occupation level in TP1, from which the early radiometric dates come, yielded no identifiable tradewares, only earthenwares. 
The excavated tradeware sherds from Allangkanangnge include a strong representation of tempayan or large stoneware jars (17 of 39 sherds, 44\%), mainly from production centres in China or Vietnam (Table 16.3). A similar ratio (1048 of 2120 sherds, 49\%) was noted for the surface collection (Table 16.1). Despite dating to a similar time frame, in other ways the excavated and surface assemblages are dissimilar. For instance, Swatow, Ming blue-and-white and Sawankhalok monochromes, the three most frequent non-tempayan classes from the surface collection, are represented by none, or at most one, of the excavated sherds. One reason for this discrepancy may be the small size of the excavated assemblage, compared to the much larger (and hence more reliable) sample obtained during the surface survey.

Two remarkable features of the Allangkanangnge tradewares are the high frequencies of early whitewares and Jizhou iron-painted wares, coupled with relatively low concentrations of early monochromes and 16th-century Chinese blue-and-white sherds. Table 16.5 shows that, in the context of all surveyed Bugis sites known to the authors, $53 \%$ of early whitewares and $64 \%$ of Jizhou sherds were obtained at Allangkanangnge, compared with just $7 \%$ of early monochromes and 16th-century Chinese blue-and-white. Allangkanangnge's high proportion of early whitewares may be attributed to the importance of Cina as an early Bugis kingdom (Bulbeck and Caldwell 2000), while its high proportion of Jizhou sherds reflects the frequent association of Jizhou wares with pre-Islamic palace centres (Caldwell and Bougas 2004). In terms of relatively high proportions of pre-Ming compared to 16th-century sherdage, the only other potentially comparable collection from a Bugis site is a small collection from Watampone (the historical capital of the major Bugis kingdom of Bone) studied by Orsoy de Flines (Table 16.5). Based on age estimates from the Bugis chronicle of Bone, its first rulers would date to the 14th century (Macknight and Mukhlis n.d.; Bulbeck 1992:Figure 13-13); regrettably, the archaeological circumstances of the Watampone sherd collection and how it may relate to the establishment of Bone are unknown.

Table 16.5: Comparison of selected Allangkanangnge tradeware classes with other Bugis collections.

\begin{tabular}{|c|c|c|c|c|}
\hline Site/s & $\begin{array}{c}\text { Early white- } \\
\text { wares }^{(a)}\end{array}$ & $\begin{array}{l}\text { Early mono- } \\
\text { chromes }^{(b)}\end{array}$ & Jizhou & $\begin{array}{c}\text { 16th-century } \\
\text { Ming }^{(c)}\end{array}$ \\
\hline Allangkanangnge ${ }^{(d)}$ & 84 & 13 & 55 & 256 \\
\hline Other Cenrana suspected palace centres ${ }^{(e)}$ & 0 & 0 & 0 & 142 \\
\hline Tosora/Sengkang ${ }^{(f)}$ & 0 & 0 & 2 & 39 \\
\hline Watampone ${ }^{(f)}$ & 9 & 13 & 2 & 1 \\
\hline Other Bone sites ${ }^{(t)}$ & 0 & 2 & 1 & 92 \\
\hline Utti Batue suspected palace centre ${ }^{(e)}$ & 1 & 0 & 3 & 271 \\
\hline Palopo tumuli(f) & 0 & 2 & 0 & 12 \\
\hline Other Luwu Bugis sites $(\mathrm{e})$ & 10 & 4 & 6 & 94 \\
\hline Tinco palace centre(g) & 13 & 79 & 3 & 284 \\
\hline Other Soppeng sites(g) & 3 & 18 & 0 & 153 \\
\hline Sidrap suspected palace centres ${ }^{(h)}$ & 13 & 10 & 5 & 781 \\
\hline Other Sidrap sites ${ }^{(h)}$ & 25 & 39 & 9 & 1525 \\
\hline \multirow[t]{2}{*}{\begin{tabular}{|l} 
Total Bugis sites \\
\end{tabular}} & 158 & 180 & 86 & 3650 \\
\hline & \multicolumn{4}{|c|}{ Percentages } \\
\hline Allangkanangnge & 53.2 & 7.2 & 64.0 & 7.0 \\
\hline Other Cenrana suspected palace centres & 0.0 & 0.0 & 0.0 & 3.9 \\
\hline Tosora/Sengkang & 0.0 & 0.0 & 2.3 & 1.1 \\
\hline Watampone & 5.7 & 7.2 & 2.3 & 0.3 \\
\hline Other Bone sites & 0.0 & 1.1 & 1.2 & 2.5 \\
\hline Utti Batue suspected palace centre & 0.6 & 0.0 & 3.5 & 7.4 \\
\hline
\end{tabular}




\begin{tabular}{|c|c|c|c|c|}
\hline Site/s & $\begin{array}{c}\text { Early white- } \\
\text { wares }^{(a)}\end{array}$ & $\begin{array}{l}\text { Early mono- } \\
\text { chromes }^{(b)}\end{array}$ & Jizhou & $\begin{array}{l}\text { 16th-century } \\
\text { Ming(c) }^{(c)}\end{array}$ \\
\hline Palopo tumuli & 0.0 & 1.1 & 0.0 & 0.3 \\
\hline Other Luwu Bugis sites & 6.3 & 2.2 & 7.0 & 2.6 \\
\hline Tinco suspected palace centre & 8.2 & 43.9 & 3.5 & 7.8 \\
\hline Other Soppeng sites & 1.9 & 10.0 & 0.0 & 4.2 \\
\hline Sidrap suspected palace centres & 8.2 & 5.6 & 5.8 & 21.4 \\
\hline Other Sidrap sites & 15.8 & 21.7 & 10.5 & 41.8 \\
\hline Total Bugis sites & 100.0 & 100.0 & 100.0 & 100.0 \\
\hline
\end{tabular}

(a) Includes Dehua and Qingbai whitewares.

(b) Includes 'Yueh' olive-greenwares and Yuan celadons.

(c) Includes Ming blue-and-white, Ming overglaze enamelled and Ming Swatow (combined).

(d) Tables 16.1 and 16.3 (this paper).

(e) Bulbeck and Caldwell (2000).

(f) Oudheidkundige Dienst in Indonesia (1949:12-13); Bulbeck (1996-97).

(g) Kallupa et al. (1989).

(h) Druce (2009); suspected palace centres include Suppak pre-Islamic centre/Makaraié/Indok Lompoa, Watang Sidenreng and Alitta.

Table 16.5 also provides a context for interpreting the histogram of tradeware datings in Figure 16.3. As documented by Kallupa et al. (1989) for Soppeng, and Bulbeck (1992) for Makassar, the available quantities of imported ceramics in South Sulawesi evidently increased continuously from the 13th/14th centuries to the 17th century, which would offer a sufficient explanation for the increase over time in the tradewares recorded for Allangkanangnge during its pre-Islamic period. That is, Figure 16.3 suggests continual occupation of at an intensive level throughout the 13th (or 14th) to 16th centuries, followed by a 17th-century decline.

\section{Historical interpretation}

The sherdage from Allangkanangnge provides clear, unequivocal evidence that the process of social complexification (state formation) in Bugis-speaking areas of South Sulawesi was underway by the 13th century AD. This process was closely linked to the availability of foreign prestige goods, of which sherds of Chinese and Southeast Asian ceramics have persisted in the archaeological records. The bulk of the exotic imports at Allangkanangnge would likely have been cloth, including Gujarati blockprint cloths, of which there are several examples from South Sulawesi highlands dated to the 14th-16th centuries (Guy 1998). Bulbeck and Caldwell (2000) have argued that trade and agriculture were two sides of the same economic coin, and that the development of complex society in South Sulawesi was a continuous process from the 13th century onwards. The two-stage 'Age of La Galigo' model of early trade-based kingdoms and post-1400 agricultural kingdoms proposed by Pelras (1996) finds no support in the historical or archaeological record. Neither does his suggestion of an intervening 'Age of Chaos' as one political economy replaced another.

The control of prestige goods imported from Java and Sumatra, and perhaps through the southern Philippines as well, and paid for by the export of rice to the Moluccas and Malacca, drove the development of Bugis political hierarchies in the 13th-17th centuries. The first driving force was symbolic, in that luxury or prestige goods articulated and promoted social hierarchy and political control. The second was the means by which these goods were paid for: with its relatively small population and extensive fertile lowlands, South Sulawesi has in most years produced more rice than its inhabitants can consume (Caldwell and Bougas 2004). When the Dutch admiral 
Cornelis Speelman sailed into the harbour at Bantaeng in 1667, he seized 800 tons of rice laden on ships for export to other parts of the archipelago (Andaya 1981:78); even today, South Sulawesi is a net exporter of rice (Hajramurni 2015). The numerous rice phytoliths recovered from TP1 in 1999 shows that rice cultivation was established at or near Allangkanangnge from the 14 th century onwards.

Estuarine shell dating from 13 th/14th century was recovered from all of the test pits, implying that the coast then lay considerably closer to Allangkanangnge than is currently the case (Hakim et al., this volume). Allangkanangnge lay on a hill overlooking a shallow valley leading to the Cenrana River, providing access to the central South Sulawesi lowlands and the coast. The valley has a flat alluvial floor, and the northern end, which abuts the Cenrana River, floods regularly in the wet season. It is possible that the valley floor as far as Allangkanangnge was once flooded, which would have made the hill an ideal location to control both the trade of imported goods into the central Bugis lowlands in return for surplus rice cultivation (Kallupa et al. 1989). Excavations around the swamps on the northern side of the Cenrana river (Nur and Hakim 2010) also indicate early wet-rice cultivation. Providing enough rice could be harvested to generate a surplus as well as meet local demand, the trade of exotic prestige goods in return for exported rice would have been lucrative for a controlling elite. The retreat of the sea, as measured by retreating estuarine influences (Gremmen 1990) could have been caused by a combination of tectonic uplift, falling sea levels during the Little Ice Age, and the accumulation of riverine silts from agriculture as lowlands and hill slopes were cleared for agriculture. These silts would over time have improved the fertility of the soils surrounding Allangkanangnge and encouraged rice production. The stratigraphically secure 14 th-century dating for the deepest rice phytoliths documented for Allangkanangnge is the oldest direct evidence for intensive rice cultivation in South Sulawesi. However, it seems probable that rice was cultivated at Allangkanangnge from initial occupation in the 13th century onwards.

\section{Conclusions}

Research on the historical archaeology of South Sulawesi's pre-Islamic polities (e.g. Kallupa et al. 1989; Bulbeck 1992; Bulbeck and Caldwell 2000; Druce 2009) has relied primarily on tradeware identifications for dating the recorded sites. Recent excavations at the Bugis palace centres of Allangkanangnge and Tinco have produced Carbon-14 determinations that match the 13th/14th-16th/17th-century dating for the bulk of the imported ceramics documented at these sites and, by extrapolation, confirm the tradeware identifications proposed for other historical sites in South Sulawesi. Allangkanangnge is of particular interest for its large assemblages of early Chinese whitewares and cream and brown Jizhou jars, especially the latter, which are predominantly associated with pre-Islamic palace centres. This site is of major importance for understanding political developments during South Sulawesi's pre-Islamic period, including the role of rice production as an economic and political staple.

\section{Acknowledgements}

The Australian Research Council funded the 1999 fieldwork by OXIS at the Allangkanangnge site and paid for one of the radiocarbon dates. The British Academy funded the 2005 fieldwork season at the site. The Centre for Archaeological Research (The Australian National University) funded two of the radiocarbon dates, and the University of Hull paid for one radiocarbon date. The Australia-Indonesia Institute funded the laboratory work on the surveyed and excavated remains. The reviews by two anonymous referees are gratefully acknowledged. 


\section{Author biographies}

David Bulbeck Department of Archaeology and Natural History, School of Culture, History and Language, College of Asia and the Pacific, The Australian National University, Canberra, Australia

Ian Caldwell Archaeological Studies Program, University of the Philippines Diliman, Republic of the Philippines

Stephen Druce Academy of Brunei Studies, Universiti Brunei Darussalam, Brunei Darussalam

Budianto Hakim Makassar Archaeology Office, Makassar, South Sulawesi, Indonesia

Campbell Macknight College of Asia and the Pacific, The Australian National University, Canberra, Australia

\section{References}

Andaya, L.Y. 1981. The Heritage of Arung Palakka: A History of South Sulawesi (Celebes) in the Seventeenth Century. Verhandelingen van het Koninklijk Instituut voor Taal-, Land- en Volkenkunde 91. The Hague: Martinus Nijhoff.

Bougas, W.A. 1998. Bantayan: An early Makassarese kingdom, 1200-1600 AD. Archipel 55(1):83-123. doi.org/10.3406/arch.1998.3444 (accessed 5 June 2018).

Bronk Ramsey, C. 2013. OxCal 4.2 manual. c14.arch.ox.ac.uk/oxcal/OxCal.html (accessed 27 October 2018).

Bulbeck, F.D. 1992. A Tale of Two Kingdoms: The Historical Archaeology of Gowa and Tallok, South Sulawesi, Indonesia. Unpublished PhD thesis, School of Archaeology and Anthropology, The Australian National University, Canberra. www.oxis.org/theses/bulbeck-1992.pdf (accessed 5 June 2018).

Bulbeck, D. 1996-97. The Bronze-Iron Age of South Sulawesi, Indonesia: Mortuary traditions, metallurgy and trade. In D. Bulbeck and N. Barnard (eds), Ancient Chinese and Southeast Asian Bronze Age Cultures, Vol. II, pp. 1007-1076. Taipei: Southern Materials Center Inc.

Bulbeck, D. 2018. Holocene site occupancy in Sulawesi. In S. O'Connor, D. Bulbeck and J. Meyer (eds), The Archaeology of Sulawesi: Current Research on the Pleistocene to the Historic Period, pp. 93-116. Canberra: ANU Press.

Bulbeck, D. and I. Caldwell. 2000. Land of Iron: The Historical Archaeology of Luwu and the Cenrana Valley. Results of the Origin of Complex Society in South Sulawesi Project (OXIS). Hull: Centre for South-East Asian Studies, University of Hull. www.oxis.org/books/land-of-iron.pdf (accessed 5 June 2018).

Bulbeck, D. and I. Caldwell. 2008. Oryza sativa and the origins of kingdoms in South Sulawesi, Indonesia: Evidence from rice husk phytoliths. Indonesia and the Malay World 36(104):1-20. doi.org/ 10.1080/13639810802016117 (accessed 5 June 2018).

Caldwell, I. 1988. South Sulawesi A.D. 1300-1600: Ten Bugis Texts. Unpublished PhD thesis, Department of History, The Australian National University, Canberra. www.oxis.org/theses/caldwell-1988.pdf (accessed 5 June 2018).

Caldwell, I. 1994. A report on fieldwork in Luwu with Bahru Kallupa and Iwan Sumantri in August 1994. Baruga 10:9-10.

Caldwell, I. 1995. Power, state and society among the pre-Islamic Bugis. Bijdragen tot de Taal-, Land-en Volkenkunde 151(3):394-421. doi.org/10.1163/22134379-90003038 (accessed 5 June 2018). 
Caldwell, I. and W.A. Bougas. 2004. The early history of Binamu and Bangkala, South Sulawesi. Bijdragen tot de Taal-, Land-en Volkenkunde 160(4):456-510. doi.org/10.1163/22134379-90003720 (accessed 5 June 2018).

Caldwell, I. and K. Wellen. 2017. Finding Cina: A new paradigm for early Bugis history. Bijdragen tot de Taal-, Land-en Volkenkunde 173(2/3):296-324. doi.org/10.1163/22134379-17302004 (accessed 5 June 2018).

Druce, S.C. 2009. The Lands West of the Lakes: A History of the Ajattappareng Kingdoms of South Sulawesi, 1200 to 1600 CE. Verhandelingen van het Koninklijk Instituut voor Taal-, Land- en Volkenkunde 261. Leiden: Martinus Nijhoff. doi.org/10.1163/9789004253827 (accessed 5 June 2018).

Fenner, J.N. and D. Bulbeck. 2013. Two clocks: A comparison of ceramic and radiocarbon dates at Macapainara, East Timor. Asian Perspectives 52(1):143-156. doi.org/10.1353/asi.2013.0005 (accessed 5 June 2018).

Gremmen, W.H.E. 1990. Palynological investigations in the Danau Tempe depression, southwest Sulawesi (Celebes), Indonesia. Modern Quaternary Research in Southeast Asia, pp. 123-134. Modern Quaternary Research in Southeast Asia, Volume 11. Rotterdam: A.A. Balkema.

Guy, J. 1986. Oriental Trade Ceramics in South-East Asia, Ninth to Sixteenth Centuries. Oxford: Oxford University Press.

Guy, J. 1998. Woven Cargoes: Indian Textiles in the East. London: Thames and Hudson.

Hadimuljono and C.C. Macknight. 1983. Imported ceramics in South Sulawesi. Review of Indonesian and Malaysian Affairs 17:66-91.

Hajramurni, A. 2011. Hundreds of artifacts unearthed in S. Sulawesi. The Jakarta Post, 4 April. www.press reader.com/indonesia/the-jakarta-post/20110401/281621006867797 (accessed 24 December 2017).

Hajramurni, A. 2015. South Sulawesi hopes to export surplus rice production. The Jakarta Post, 23 January. www.thejakartapost.com/news/2015/01/23/south-sulawesi-hopes-export-surplus-rice-production. html (accessed 24 December 2017).

Hakim, B., S. Hawkins, D. Bulbeck, I. Caldwell, S. Druce and C. Macknight. 2018. Material culture at Allangkanangnge ri Latanete in relation to the origins of Bugis kingdoms. In S. O'Connor, D. Bulbeck and J. Meyer (eds), The Archaeology of Sulawesi: Current Research on the Pleistocene to the Historic Period, pp. 287-312. Canberra: ANU Press.

Harrisson, B.V. 1990. Pusaka: Heirloom Jars of Borneo. Singapore: Oxford University Press.

Hasanuddin. 2015. Kebudayaan Megalitik di Sulawesi Selatan dan Hubungannya dengan Asia Tenggara. Unpublished PhD thesis, Centre for Archaeological Research Malaysia, Universiti Sains Malaysia, Kuala Lumpur. www.oxis.org/theses/hasanuddin-2015.pdf (accessed 5 June 2018).

Kaharuddin. 1994. Permukiman Kuno Allangkanangnge ri Latanete Kecamatan Pammana Kabupaten Wajo. Unpublished Bachelor of Arts thesis, Hasanuddin University, Makassar.

Kallupa, B., D. Bulbeck, I. Caldwell, I. Sumantri and K. Demmanari. 1989. Survey Pusat Kerajaan Soppeng 1100-1986 [Survey of the Capital of Soppeng Kingdom 1100-1986]. Final Report to the Australian Myer Foundation, Privately published in Canberra, ACT. www.oxis.org/books/soppeng-1986.pdf (accessed 5 June 2018).

Macknight, C.C. 1983. The rise of agriculture in South Sulawesi before 1600. Review of Indonesian and Malaysian Affairs 17:92-116.

Macknight, C.C. and P. Mukhlis. n.d. The Chronicle of Bone. Unpublished typescript. 
Naniek, H.M.T. 1983. Ceramics from Selayar: A preliminary study. SPAFA Final Report, Workshop to Standardize Studies of Ceramics of East and Southeast Asia, pp. 75-92, Southeast Asian Ministers of Education, Project in Archaeology and Fine Arts, Cebu City, Philippines.

Nayati, W. 2005. Social Dynamics and Local Trading Patterns in the Bantaeng Region, South Sulawesi (Indonesia) circa 17th Century. Unpublished PhD thesis, The Southeast Asian Studies Programme, National University of Singapore, Singapore. www.oxis.org/theses/widiya-nayati-2005.pdf (accessed 5 June 2018).

Nur, M. and B. Hakim. 2010. Telaah awal tembikar Wajo. Walennae 12(2):189-194.

Oudheidkundige Dienst in Indonesia. 1949. Oudheidkundig Verslag 1948. Bandung: A.C. Nix \& Co.

Pelras, C. 1996. The Bugis. Oxford: Basil Blackwell.

Robson, S. (translator). 1995. Désawanana (Nagarakrtagamana) by Mpu Prapañca. Leiden: KITLV Press.

van Heekeren, H.R. 1958. The Bronze-Iron Age of Indonesia. Verhandelingen van het Koninklijk Instituut voor Taal-, Land- en Volkenkunde 22. The Hague: Martinus Nijhoff.

Wibisono, C.S. 1985. Sebaran situs kubur sebagai studi awal pola pemukiman di Pulau Selayar. Rapat Evaluasi Hasil Penelitian Arkeologi II, pp. 370-383, Pusat Penelitian Arkeologi Nasional, Jakarta.

Zainal Abidin, A. 1974. The I La Galigo epic cycle of South Celebes and its diffusion. Indonesia 17:160-169. doi.org/10.2307/3350778 (accessed 5 June 2018). 
This text is taken from The Archaeology of Sulawesi: Current Research on the Pleistocene to the Historic Period, edited by Sue O'Connor, David Bulbeck and Juliet Meyer, published 2018 by ANU Press, The Australian National University, Canberra, Australia.

doi.org/10.22459/TA48.11.2018.16 